Article

\title{
Domestic Socioeconomic Barriers to Hydropower Trading: Evidence from Bhutan and Nepal
}

\author{
Kaoru Ogino ${ }^{1}$, Mikiyasu Nakayama ${ }^{2}$ and Daisuke Sasaki ${ }^{3, *}$ \\ 1 Asian Development Bank, Manila 1550, Philippines; kogino@adb.org \\ 2 Graduate School of Frontier Sciences, The University of Tokyo, Chiba 277-8563, Japan; \\ nakayama@k.u-tokyo.ac.jp \\ 3 International Research Institute of Disaster Science, Tohoku University, 468-1 Aoba, Aramaki, Aoba-ku, \\ Sendai 980-0845, Japan \\ * Correspondence: dsasaki@irides.tohoku.ac.jp; Tel.: +81-22-752-2094
}

Received: 26 February 2019; Accepted: 3 April 2019; Published: 7 April 2019

check for updates

\begin{abstract}
Bhutan has increased exports of surplus hydropower generation, whereas Nepal has been suffering from domestic power shortages. Why has Bhutan successfully promoted hydropower development and exports, while Nepal has failed to do so? This paper focuses on inherent development barriers that stem from domestic power supply, internal governance systems, and indigenous societal sensitivity. There are lessons to be learned from Bhutan's practices that could be applied in Nepal. First, hydropower development can be severely affected by electricity scarcity that arises when power export is privileged over domestic power supply. Nepal has fallen into this negative loop, whereas Bhutan has overcome it through policy interventions that ensure visible links between power exports and domestic power consumption. Second, the sector reforms in the two countries contrast in terms of institutional, operational, and financial efficiency. Without fundamental reforms, Nepal's sector-wide inefficiency fuels a vicious circle. Third, local resource conflicts and social complexities have made Nepal's hydropower projects more complicated than Bhutan's. In planning hydropower projects, it is crucial to pay careful attention to domestic stakeholders and local benefits. Planners and governments must ensure that projects are designed with extensive benefit sharing mechanisms, sustainable value chains, effective sector reforms, and sufficient societal conflict management.
\end{abstract}

Keywords: Bhutan; hunger export; hydropower; Nepal; power export

\section{Introduction}

Countries with large potential for hydropower generation can obtain huge benefits by connecting their hydropower stations to transboundary power grids and trading electricity with other nations [1]. This has been the case for Bhutan where hydropower export to India has brought significant economic benefits and contributed to fast-paced gross domestic product (GDP) growth. In contrast, Nepal has not profited from its closer proximity to India's power-hungry areas and its greater hydropower potential. On the contrary, Nepal has been suffering from chronic domestic power shortages and must address this issue before considering power exports to other countries. Indeed, since 2016, Nepal has started importing power from India to alleviate the domestic power crisis.

During these last few decades, Bhutan's generation capacity has grown to become almost double that of Nepal's despite Bhutan's smaller land area and population as shown in Table 1. Likewise, the gap between the two countries' per capita GDP values has been widening, with Bhutan's per capita GDP being three times as large as Nepal's in 2015. Along with the economic growth, Bhutan has used part of its power export revenues to fulfill domestic socioeconomic needs, including rural 
electrification services. As power exports have increased, Bhutan has accelerated electricity access for households and achieved a national electrification ratio of almost 100\%. Moreover, Bhutan has maintained the cheapest electricity rates in South Asia. In contrast, Nepal has achieved electrification of just over half of its households through grid extension and its average retail tariff on electricity is more than double Bhutan's.

Table 1. Country and power sector data comparison between Bhutan and Nepal.

\begin{tabular}{ccc}
\hline Item & Bhutan & Nepal \\
\hline Country data: & & \\
\hline Surface area $\left(\mathrm{km}^{2}\right)$ & 38,117 & 143,350 \\
Population (2015) & 787,386 & $28,656,282$ \\
Per capita GDP (US\$) (2015) & 2656 & 743 \\
\hline Power sector data: & & \\
\hline Economically feasible hydropower potential (MW) & 26,760 & 43,000 \\
Installed generation capacity (MW) (2016) & 1614 & 856 \\
Electrification ratio (\%) excluding off-grid cases (2015) & 53 \\
Average electricity retail tariff (US cent/kWh) (2015) & 37 & 8.4 \\
\hline
\end{tabular}

$\mathrm{GDP}=$ gross domestic product. ${ }^{1} \mathrm{Nepal}^{\prime}$ s overall electrification ratio is estimated at $75 \%$ [2], $22.2 \%$ of which is estimated to be off-grid, and Bhutan's overall electrification ratio is estimated at $98 \%$ [3], 1.2\% of which is estimated to be off-grid. To estimate these off-grid electrification rates, the following data were used: (i) the number of Nepal Electricity Authority (NEA) residential households with grid connections [4], (ii) the total number of households in Nepal from census data [5], (iii) the number of off-grid households in Bhutan from the Bhutanese government official [6], and (iv) the total number of households in Bhutan, estimated by Bhutan's population data [7] divided by the average family size [8]. Sources: [2-14].

Why has Bhutan successfully reaped benefits from hydropower development and export while Nepal has failed to do so? In response to this question, there have been numerous attempts to analyze and identify both the barriers and facilitating factors operating in each country. Most of these studies focus on Bhutan's and Nepal's diplomatic relations with India and on geopolitical stability in the region. For example, it has been argued that Bhutan has twice the hydropower capacity and power exports due to Indian-built plants in Bhutan, and that Nepal's political instability created delays in its hydropower development, which resulted in its internal power crisis $[15,16]$. In fact, Bhutan has largely used India's bilateral assistance for hydropower and economic development, but Nepal was unwilling to allow India to access its hydropower resources on comparable terms [17]. It has also been pointed out that in contrast to the successful bilateral case of Bhutan and India, the last 20 years have proved to be missed opportunities for Nepal and India because of continuing mistrust due to the "big brother-small brother syndrome" [18]. Setting aside these external elements and political relations with India, however, few among the preceding studies have compared and examined the internal factors responsible for the differences between Bhutan and Nepal from the perspective of their domestic circumstances. For example, it is often highlighted that Bhutan is more advanced in hydropower exporting than Nepal and this has created an advantageous relationship for Bhutan with India. However, such export business cannot be segregated from the domestic requirements for power consumption that must be addressed before selling power outside the country. Some people argue that domestic rural electrification should precede power exports. In this case, Nepal's larger population and land size should be considered a critical bottleneck for power export plans as they make it difficult to electrify domestically. Should the domestic power supply really be required before the country can start considering power exports? In other words, should power exports be disallowed before achieving domestic electrification? None of the existing research has clarified in detail whether power exports and domestic consumption are antithetical with each other or not. Furthermore, these two schemes should be controlled by government domestic policies to some degree, but it is uncertain what kind of regulatory frameworks are available for these different purposes of hydropower usage in these countries. In the case of hydropower-rich countries, like Bhutan and Nepal, these frameworks should 
eventually be an integral part of sector-wide structures and systems at their country levels. At the same time, often, hydropower development sites are located in remote areas and entrenched in local communities. Thus, local reactions and voices cannot be ignored on the societal level. Nevertheless, the effects of wide-ranging domestic issues have not been analyzed comprehensively in considering approaches to hydropower development, particularly for purposes of power export or domestic consumption from the viewpoint of domestic electricity uses and stakeholders.

\section{Materials and Methods}

The current development outcomes clearly indicate that, while Bhutan has successfully developed its key hydropower projects and brought about economic growth, Nepal has failed to do the same. In fact, Bhutan has never stopped any hydropower development projects approved by the government for funding, but Nepal has historically suspended development of some key projects in the middle of their funding process. These include the Arun III hydroelectric project and the West Seti hydroelectric project, both originally designed to be export-oriented. The former was expected to be funded by the World Bank during the early 1990s, and the latter by the Asian Development Bank (ADB) during the late 2000s to the early 2010s. However, both funding proposals were eventually withdrawn having encountered domestic barriers and difficulties because of their power export-oriented design. Why did Nepal's projects face these issues when Bhutan's did not? Clarifying the reasons for Bhutan's success and Nepal's failure should provide insights into hydropower projects in exporting countries.

Based on the analyses of some case projects, the two countries' historical development profiles were examined through the value chains of power supply from generation to distribution. This is because generation planning should be based on the power supply requirements of the end-users of the electricity, including consideration of domestic energy security. The contrasts between Bhutan and Nepal were assessed on different elements of the value chains, such as customer types, rural and urban supplies, pricing mechanisms, and demand and supply gaps. Moreover, the analysis was extended to compare the outcomes from domestic politics and their influence on institutional and governance systems. Finally, local societal changes in the two countries were compared.

Thus, this paper analyzes the different layers at play in each country's internal circumstances, focusing in particular on (i) domestic power supply, (ii) domestic policies and sector reforms, and (iii) inherent societal sensitivity and resilience to hydropower development, to identify the specific causes of the development gap between Bhutan and Nepal in terms of hydropower development and its export. Based on the findings, the conclusion suggests the policy elements and priorities to be considered by policy makers, developers, and financers.

As the research method, interviews with government officials and national utility staff were conducted during field visits. Further studies were carried out based on reviews of earlier literature, statistical macroeconomic and demographic data, government sectoral plans and strategy papers, utilities' annual reports, and bilateral and multilateral agencies' documents.

\section{Results and Discussion}

\subsection{Domestic Power Supply}

As a result of domestic power shortages, power export project proposals have often been controversial and emotionally fraught in Nepal. For example, from the late 2000s to the early 2010s, a private developer-the Austrian Snowy Mountains Engineering Corporation-tried to promote the West Seti hydropower storage project (750 MW) for power export from Nepal to India [19]. At that time, it was argued that the electricity generated by the West Seti dam should be consumed in Nepal instead of being exported to India, as most Nepalis did not have access to electricity in their homes [20]. Some candid questions such as the following were articulated: (i) Why do power exports need to be considered when there is a power shortage, or no power supply at all, in many rural areas of Nepal? (ii) Why should the needs of Nepal's people be affected and sacrificed in order to benefit a neighboring 
country through power exports? To respond to these concerns, the project intended to allocate part of the generated power to domestic consumption as the project's royalty payment to the government. However, this part of the scheme was ignored by a public more attuned to the emotional appeal of the voices protesting against the sacrifice of their compatriots' interests.

Even before the West Seti project proposal, the Arun III hydroelectric project also faced a similar issue during the early to mid-1990s. The real situation was twisted, even though (i) the Arun III project was assessed as non-controversial as it was based on a run-of-the-river design with no significant social and environmental impacts, and (ii) there was significant consensus in favor of the project itself in local communities because of the benefits of new road construction $[17,21,22]$. Small groups of activists criticized the project by saying that it would take too long to educate the local villagers about the project's long-term negative impacts [17]. The possible local sacrifices were used as an important basis for domestic and international opposition in the so-called anti-Arun III campaigns. Over time, a considerable number of Nepali people, including much of the Kathmandu urban middle class, became sympathetic to these campaigns given the background of perennial power shortages in the country [23]. The common resistance against these two project proposals was based not only on a mix of sympathetic reactions to compatriots and antagonistic feelings toward India, but also on the fear of export-caused scarcity-i.e., that power export to India would decrease the domestic power supply. The fear of export-caused scarcity of electricity is not a special case in Nepal alone. For example, there was a similar concern in the recent Sahara Desert solar project proposal that aimed to export solar power to Europe. It highlighted an internal issue in the exporting countries, such as Morocco and Tunisia, namely, the failure of these countries to meet more domestic electricity needs before considering exporting power [24]. Export of electricity in a power-hungry domestic situation can be considered as a "hunger export", equivalent to the situation seen with famine problems due to excessive food export. The Arun III project was further jeopardized by a series of compliance issues with the World Bank's rules and procedures, and the World Bank eventually decided to withdraw its funding. Financing for the West Seti project was also withdrawn by the ADB in 2010. These cases indicate the importance of weighing domestic electricity needs against the potential benefits of electricity export.

Bhutan dealt with this issue by starting to export power to India in the late 1980s. However, it almost completed the electrification of all domestic households throughout the country only very recently [25]. This means that Bhutan undertook power export even though the domestic power supply could not meet the needs of the whole population. In fact, although Bhutan had electrified only $36 \%$ of all households as of 2004 [26], it exported more than half of the power generated in the country at the time. Based on the national master plan for rural electrification formulated in 2005 [26], Bhutan rolled out and accelerated a series of rural electrification programs during this decade, and almost achieved the target of the master plan. As of 2015, the national electrification ratio stood at $98 \%$ of all households [3], whereas Nepal's corresponding ratio was $75 \%$ [4]. This sharp difference in total electrification ratios turns into an even wider gap when we contrast the two countries' grid electrification. The off-grid electrification ratios can be estimated at $1.2 \%$ for Bhutan and $22.2 \%$ for Nepal, respectively (see Table 1). These data mean that the grid-connected electrification ratios are $97 \%$ for Bhutan and 53\% for Nepal. Thus, Nepal's grid connection to households still covers only half of all households; one third of the electrified households are on an off-grid basis, and one out of four households in Nepal has no access to electricity.

In contrast, Bhutan minimized off-grid electrification as consumers were not very happy with off-grid solar home systems, mainly because (i) its power supply capacity is limited to use for lighting and small electrical appliances and does not provide enough for cooking and heating purposes, and (ii) its availability depends on sunny conditions and solar battery life. In Bhutan, therefore, the off-grid option was treated as the last resort and used only for rural electrification in very remote areas where grid extension was economically unfeasible. Bhutan has thus paid attention to an effective scheme of domestic electrification, while promoting hydropower export projects in parallel. This approach taken 
by Bhutan suggests that exporting electricity is still feasible even when domestic electrification needs are not fully met, provided that the electrification coverage is steadfastly expanded and promoted in tandem with power exports [27]. Bhutan's practices also indicate that the government and its utilities have demonstrated a balanced approach between domestic power supply and power export, using rigorous schemes and careful designs that took into account domestic electricity users' satisfaction and perceptions.

In the case of Nepal, the grid connection has been slow, particularly in rural areas where the population is larger than urban areas. Most rural people have no electricity or a limited power generation capacity through an off-grid system. Although a series of relevant policies were formulated in Nepal to promote rural electrification, these policies lacked clear action plans and the tools to achieve them [28]. Urban residents have also suffered from an unstable power supply and chronic load-shedding blackouts, particularly during the dry winter seasons. Kathmandu has sometimes scheduled blackouts of $18 \mathrm{~h}$ a day during this season [29]. Thus, domestic power shortage problems have been visibly and widely experienced by Nepali residents in two forms: (i) lack of rural electrification, and (ii) load-shedding blackouts. In practice, the latter is more serious than the former. This is because nowhere is Nepal's power crisis more apparent than in the load-shedding blackouts, which have met with severe criticism from the public and in the media. In Bhutan, load shedding was implemented in the past, but only for industrial customers. This was not very difficult because there were only 16 industrial customers with high voltage supply, including large energy consuming industries such as cements and ferro-alloys. They were energy intensive industries whose usage amounted to three-fourths of Bhutan's national electricity consumption as shown in Table 2.

Table 2. Percentage of customer category-wise number of individual customers and volume of electricity sales in Bhutan and Nepal (2015).

\begin{tabular}{ccccc}
\hline Customer Category & \multicolumn{2}{c}{ Bhutan } & \multicolumn{2}{c}{ Nepal } \\
\hline & $\begin{array}{c}\text { Number of individual } \\
\text { customers (\%) }\end{array}$ & $\begin{array}{c}\text { Volume of total } \\
\text { electricity sales (\%) }\end{array}$ & $\begin{array}{c}\text { Number of individual } \\
\text { customers (\%) }\end{array}$ & $\begin{array}{c}\text { Volume of total } \\
\text { electricity sales (\%) }\end{array}$ \\
\hline Industrial & 0.3 & 74 & 2 & 32 \\
Residential & 83 & 11 & 94 & 48 \\
Other (e.g., commercial) & 17 & 15 & 4 & 20 \\
\hline Total & 100 & 100 & 100 & 100 \\
\hline \multicolumn{5}{c}{ Sources: $[3,4]}$.
\end{tabular}

In Bhutan, the majority of individual customers are residential households, comprising $83 \%$ of all Bhutanese customers; however, they used only $11 \%$ of the total electricity supply. Under these circumstances, it was easier to control industrial consumption without affecting the electricity supply for residential customers. In Nepal, the residential households' consumption amounts to almost half of the national electricity use and is greater than industrial consumption (see Table 2). As a result, Nepali residential customers have also been included in load-shedding targets. During the winter of 2016 and spring of 2017, because of bulk power imports from India, the load balance was alleviated, and load shedding was limited to industrial customers only. Of course, it is not a good policy to continue to cut the power supply of the industries that sustain the economy, but this temporary action was widely supported and accepted within Nepal. It was considered less painful than for residential households to have no electricity in the evening peak time, typically from 6:00 p.m. to 10:00 p.m.

In Nepal, unlike in Bhutan, the chronic power cuts have raised concerns and doubts, and changed people's perceptions, instilling in the population the fear of export-caused electricity scarcity: a power hunger. Understandably, this fear can then trigger reluctance or opposition to any power export projects so long as such a situation endures. Although hydropower project developers, investors, and financers generally treat power export to India as more attractive than domestic consumption in terms of credit risks, the lack of local support can make these actors cautious and slow down development processes-and the same caveat can be extended to any type of hydropower project, whether for power export or domestic consumption. This has led to a longer gestation period for 
projects involving the promotion of concrete project plans, consultations, financial closures, and the implementation processes. As the entire process becomes longer, hydropower projects are delayed and the domestic power balance becomes more fragile. In the unending negative cycle that follows, it becomes harder to avoid load shedding. In addition, rural electrification cannot be promoted without ensuring that the source of the power supply for increased domestic consumption is an integral part of power generation projects. This is how Nepal has fallen into the vicious circle of export-caused electricity scarcity in this current context (see Figure 1).

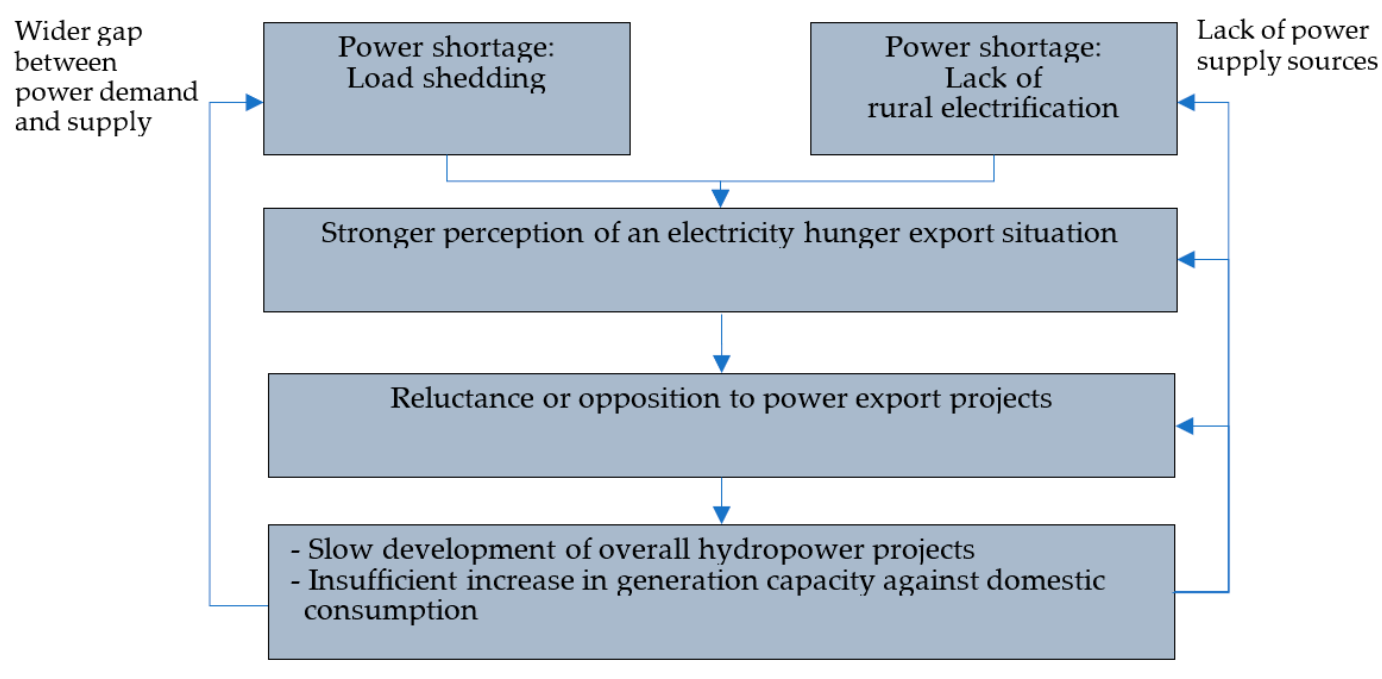

Sources: Authors.

Figure 1. Nepal's vicious circle of power scarcity in the context of a potential electricity hunger export.

In Bhutan, load shedding was minimized and contained to occasional cases during the dry winter time and directed only at large industries. Therefore, households have not experienced load shedding and residents do not perceive any power shortage. Indeed, Bhutan has not experienced export-caused electricity scarcity, particularly for residential households. This is partly because their hydropower plants are not allowed to export power before meeting the domestic power demand: only surplus generation has been exported after domestic power needs are met. Thus, Bhutan's domestic power demand has basically been satisfied, and there is no concern about export-caused electricity scarcity in the current situation. As a result, hydropower exports have been generally supported by the public. Based on the public support, a series of hydropower projects have contributed to increasing the hydropower capacity available for the growing domestic demand with the understanding that the power generated must first be used to meet domestic electricity needs before export is considered.

In addition to the priority granted to the domestic power supply over power export, Bhutan has imposed another obligation. Hydropower projects with more than $25 \mathrm{MW}$ capacity must provide royalties in the form of power to the government whether their purpose is for power export or domestic consumption, and whether their financing is through public or private investments. This policy requires that $12 \%$ of any power generated must be given to the government as energy royalties during the first 12 years of operations and 18\% thereafter. In Nepal, the royalty is set at $1 \%$ of the electricity sales of any generators, including the Nepal Electricity Authority (NEA) and private independent power producers as per the Nepal Electricity Act (1989). The energy royalties can be paid in cash to the government and are first to be used for subsidies to residential and commercial electricity users. Considering the socio-economic situation, the government decides subsidy levels for a number of customer classes grouped by electricity consumption ranges. In Bhutan, the industrial customer class is excluded from the tariff subsidies, and households are categorized depending on the monthly electricity consumption; more subsidies are generally allocated to categories that use less electricity. Therefore, this regressive subsidy scheme is treated as part of Bhutan's social programming. The subsidies 
are given by the government to the national utility, Bhutan Power Corporation (BPC), and used to lower its electricity charges to the corresponding domestic customer classes. This mechanism ensures that part of the revenues foregone from power exports are redistributed to domestic customers, and that some potential returns from hydropower exports are shared with the domestic electricity users. This benefit-sharing mechanism allows the domestic customers to pay lower prices for their electricity use because of power export projects. Because of its power exports and royalty benefit sharing with domestic customers, Bhutan has maintained much lower average domestic tariffs than Nepal (see Table 1. To make this system transparent, the sector's regulator has also disclosed the true costs of the power supply for each customer class and how much of those costs are subsidized from the benefits of hydropower projects. As a result of benefit sharing, therefore, public opinion can be incentivized to support hydropower projects and more exports.

The Bhutanese government has further collected power export revenues in the form of taxes and dividends from power generation companies and has spent them mainly on the country's socio-economic services, such as health, education, and rural development. Rural electrification was also promoted as part of social services in a programmatic manner as per the development master plan. This master plan was prepared to formulate detailed implementation schemes that concretely indicate how many households need to be electrified in each district and village, and used technical and economic analyses to determine which areas should be electrified by means of grid connections or with off-grid systems through micro-hydro or solar power schemes.

Bhutan's hydropower exports and domestic power supply, as well as socio-economic services, have been interrelated and promoted in tandem. Thus, in contrast with Nepal, Bhutan has been in a virtuous development circle along with some policy interventions as shown in Figure 2.

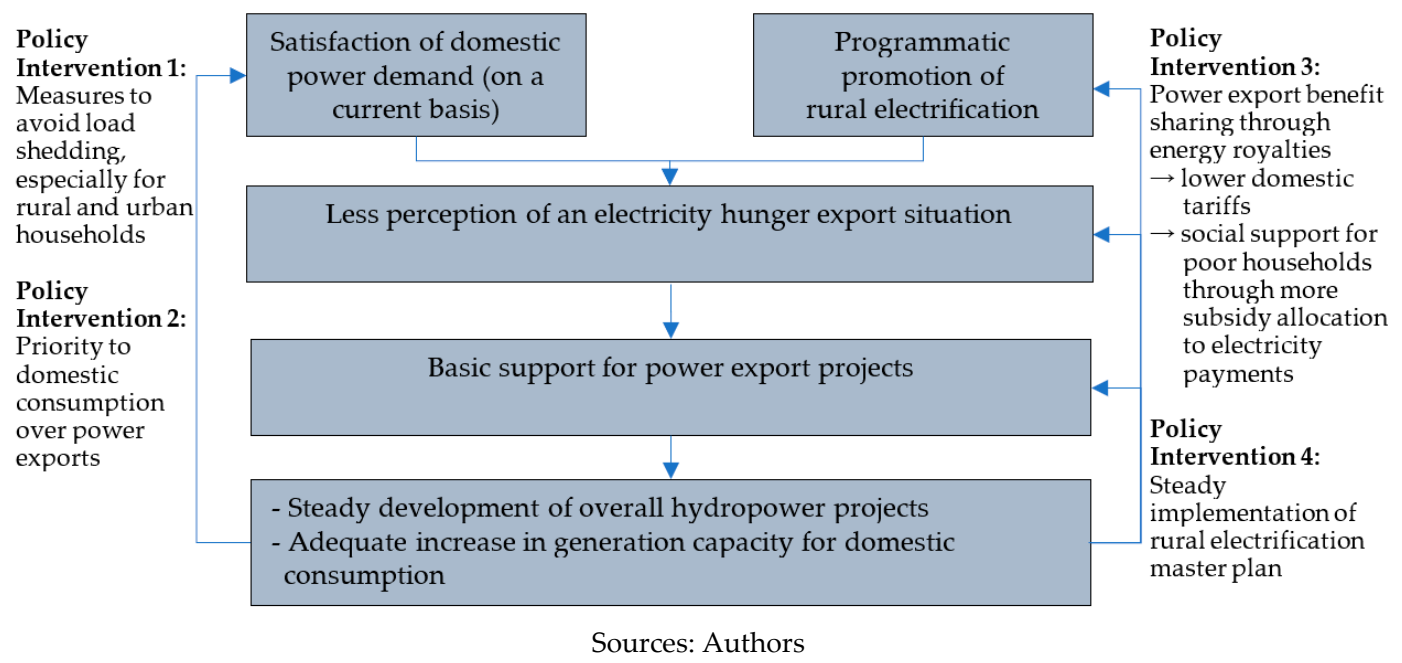

Figure 2. Bhutan's virtuous circle of power supply in the context of a potential electricity hunger export.

In summary, the above comparison of the two countries indicates how important it is to care about the domestic power supply and electricity users in planning power export projects. It is crucial to understand that power export and domestic power consumption cannot be separated when considering sectoral strategies and devising a country-wide development plan. The bottom line in the pursuit of these two objectives is domestic energy security. In this sense, it was quite reasonable that the ADB supported the Dagachhu hydropower investment in Bhutan and rural electrification expansion at the same time in a single financing project [9]. To ensure benefits from power exports for domestic poverty reduction, the project included parallel investment in widening energy access for the rural poor [30]. Is it possible to see the same direction for Nepal? In reality, Nepal's much larger land area and population would make it more difficult to quickly achieve electrification throughout the country. Nepal's land area is almost four times larger and its population 36 times larger than Bhutan's. 
It would likely take longer and cost much more for Nepal to achieve $100 \%$ electrification. However, it is not necessary to complete rural electrification too hastily. The population and land sizes are not the critical factor in Nepal's problems. It is, rather, crucial to take appropriate measures to break up Nepal's vicious development circle (see Figure 1).

For this purpose, there are important lessons to be learned from Bhutan's practices. As the first policy intervention, focus was given to efforts to minimize and eliminate load shedding in order to meet the current domestic power demand, setting aside potential future demand from unelectrified customers. This is because domestic electricity customers' frustration with blackouts can generate immediate criticism and negative reactions against export-caused electricity scarcity. Therefore, it is crucial to satisfy current domestic demand and eliminate load shedding as the first priority. To minimize the load shedding for residential customers, Bhutan imported power from India (the states of West Bengal and Assam) during the lean seasons in winter, even though this caused it to lose its profits. For example, the 2013 import price was 2.46 Bhutanese ngultrums $/ \mathrm{kWh}$, which was more expensive than Bhutan's retail tariffs of 2.17 Bhutanese ngultrums $/ \mathrm{kWh}$ approved for residential customers under low voltage from 2013-2016 [10]. As the second policy step, the domestic power supply, rather than power exports, was clearly defined as the priority for power generation. In power purchase agreements, power exports should be allowed only from the surplus after the domestic demand has been met. As the third step in the effective policy approach, the benefit-sharing mechanism by means of royalty payments was also devised as an integral part of the domestic electricity pricing systems and regulations. This allowed Bhutan to improve public and local support for hydropower projects even in the context of an electricity hunger export situation before full electrification was achieved. The fourth policy was to define a clear and feasible master plan to implement rural electrification. By demonstrating steady achievement of yearly targets for rural electrification as per the master plan, Bhutan accelerated rural electrification programs and achieved almost 100\% electrification in 2016, prior to the initial policy target of 2020. Bhutan's development experience thus suggests that while promoting power export projects, domestic power demand can be met by prioritizing the domestic power supply, crafting supportive policies, establishing an effective benefit-sharing scheme, and making progress in rural electrification.

\subsection{Domestic Politics and Sector Reforms}

Fundamental changes in Bhutan and Nepal can be viewed from the perspective of the sector's governance structures and their effects. Bhutan and Nepal have, for decades, experienced contrasting situations in terms of domestic political stability. Bhutan adopted a constitutional monarchy system in 2007 and started a national assembly through its first democratic elections in 2008. In 2013, the country had its second national election, which changed the ruling party. The government's ministries were also reorganized and streamlined in a series of structural and legal reforms. Nevertheless, Bhutan has been politically stable as the core bureaucratic systems and officials have been maintained. In contrast, Nepali politics have been volatile. Since 1990, there have been more than 25 governments. Every time a new government assumed power, new ministers were appointed, and the government's bureaucrats and public enterprise management were also replaced. During this period, Nepal experienced a civil war through the Maoist insurgency that lasted 11 years, from 1996 to 2006. There was also the dramatic end of the monarchy system in 2008 and a tragic earthquake in 2015. The Nepali coalition governments tend to go for political power balancing arrangements, which undermine confidence and delay economic reforms [31]. Thus, Nepal's political instability and weak governance systems have had adverse effects on the business and investment climate [32], and have discouraged foreign investments [33].

According to the World Bank assisted survey on hydropower development in Nepal [34], the top barrier to hydropower development was an unstable political situation, followed by lack of institutional capacity, such as rigorous development plans and coordination on hydropower and transmission. In effect, the contrasting domestic political situations in Bhutan and Nepal have been reflected in 
their internal decision-making, planning, and implementation processes in the energy-producing sector as well as in institutional reforms. In the 2000s, the government of Bhutan implemented a series of sectoral reforms, which included the issuance of the sector's act, the creation of the sector's regulations and definition of the role of a regulator, institutional unbundling to segregate the power generation business from transmission and distribution operations, and a private participation policy. Nepal, on the other hand, has been debating similar measures for more than a decade. The Nepal Electricity Authority (NEA) continues to be vertically integrated as it has been since 1985, and its financial performance is still not up to par.

In contrast, Bhutan's Druk Green Power Corporation (DGPC), the national generation utility, and BPC, the national transmission and distribution utility, have been financially healthy, and their tariffs and operational performance have been regulated to promote efficiency and transparency. The sector's reforms and performance improvements are in harmony with the pace of the country's hydropower development and domestic electrification. Price and Mittra [27] have pointed out that Bhutan's institutional arrangements evolved as the hydropower sector developed. In fact, after BPC was spun off from the government ministry in 2002 and became a corporation, the pace of rural electrification accelerated in Bhutan. Since DGPC was established in 2008, several large hydropower projects have been promoted and implemented in parallel. Proper institutional setup under the sector reforms has driven both hydropower development and rural electrification in Bhutan. At the same time, the sectoral regulatory regime was introduced, and financial and operational performance has been planned, measured, and controlled in an appropriate manner through a check-and-balance mechanism under the auspices of the sector regulator. These sectoral changes are missing in Nepal, and both hydropower and electrification development have stopped or slowed down. In the meantime, the NEA's financial performance has deteriorated, while the domestic demand and supply balance have worsened so that it is not even possible to consider any power exports. The NEA's capacity problems often draw intense criticism within Nepal, but these problems are deep-rooted in the sector itself and at the policy level. In a working paper, the World Bank also asserted that poor financial and operational performance in the power sector reflects the structure of sector governance [35].

In terms of corporate governance, the NEA's fundamental institutional problems reside in the lack of proper management and planning control rather than in its staff members' level of experience and capability. The head of NEA's management has frequently been replaced by the government, and its planning activities are then discontinued. The NEA chairperson's position has been held by the energy minister, except during the period 2011-2012 when the secretary of the energy ministry became the chairman of the NEA. The decision-making processes have been highly politicized. As the government's administration has been replaced each time a party assumes power, the NEA's management positions-including the chairpersons, management directors, and line directors-have also been changed almost every year. The NEA, thus, has had difficulty in maintaining its continued autonomous management to deal with planning and executing projects and operations for a certain period. As a result, the NEA management's attention to a project and its decision-making capability, as well as its presence at the site, were inadequate, and, as the responsible institution, the NEA was not willing or able to resolve various issues in a timely fashion [36]. It was evident that a series of NEA projects were delayed due to the absence of timely project site management pertaining to changes in designs, disputes with bidders/contractors, and labor strikes during construction. Nevertheless, the government has not implemented effective sector reforms or supported NEA restructuring processes because there has been no stable administration with the political capacity to enforce such a fundamental change. Thus, the Nepali power sector is caught in another vicious circle originating in the institutional obstacles embedded in the sector itself. The management performance of the government and NEA has been inadequate and unstable, and their structural performances have deteriorated.

Table 3 compares the average domestic retail tariffs and costs of electricity supply in Bhutan and Nepal. The tariffs have been determined by the sector's regulators. For example, Bhutan has revised 
the domestic retail tariffs every year based on the cost and revenue performance of BPC as per its tariff determination regulations. Owing to the subsidies sourced from royalties diverted from the hydropower exports, Bhutan's domestic retail tariffs have been maintained lower than Nepal's as seen in the previous Section 3.1 (Domestic power supply). In Nepal, the average retail tariff is much higher, equivalent to 8.4 US cents $/ \mathrm{kWh}$, whereas the corresponding Bhutan tariff is $3.7 \mathrm{US}$ cents $/ \mathrm{kWh}$. Nepal's tariffs have been high historically and, even worse, the costs of power supply have been much higher than the tariffs. As indicated in the table, the average cost of power supply in Nepal is much higher than in Bhutan (Nepal's cost of supply was 11.9 US cents/kWh, while Bhutan's was 4.1 US cents/kWh).

Table 3. Average retail tariffs and costs of power supply, and cost recovery (2015).

\begin{tabular}{ccc}
\hline Tariff and Costs of Power Supply & Bhutan & Nepal \\
\hline Average cost of supply (US cent $/ \mathrm{kWh})^{1}(\mathrm{~A})$ & 4.1 & 11.9 \\
Average retail tariff (US cent $/ \mathrm{kWh})^{1}(\mathrm{~B})$ & 3.7 & 8.4 \\
Average subsidies (US cent $/ \mathrm{kWh})^{1}(\mathrm{C})$ & 1.3 & \\
Cost recovery tariff $(\mathrm{US} \text { cent } / \mathrm{kWh})^{1}(\mathrm{D}=\mathrm{B}+\mathrm{C})$ & 5.0 & 8.4 \\
Cost recovery $(\%)(\mathrm{E}=\mathrm{D} / \mathrm{A})$ & $122 \%$ & $71 \%$ \\
\hline
\end{tabular}

1 The exchanges rates against the US dollar (i.e., 100 US cents) are 65 Bhutanese ngultrum and 102 Nepali Rupees. Sources: $[3,4,11]$.

The main reasons for the high Nepali costs are (i) high power purchase costs from India and domestic private independent power producers (IPPs), and (ii) Nepal's high system losses in transmission and distribution systems. Because of the domestic power shortage, the NEA has been increasing the amount of power it purchases, which now makes up more than half of the total electricity available in Nepal. (The NEA's own generation constitutes only $43 \%$ of the total available; imports from India and purchases from local IPPs constitute 57\% [4]). The average cost of power purchased from IPPs and India is very high at $8.1 \mathrm{US}$ cents $/ \mathrm{kWh}$ [4]. As there are a large number of small-scale IPPs each generating a small volume of electricity, their unit costs tend to be high. However, the NEA has signed power purchase agreements with them. Likewise, importing power from India is expensive, but the NEA has purchased Indian electricity to compensate for the domestic power shortage in Nepal. Public opinion may consider this power purchase cost structure as being responsible for Nepal's high operational costs, irrespective of the NEA's own generation costs. In addition to the generation side, the transmission and distribution systems are problematic in Nepal. Because of poor maintenance, the average system loss (i.e., electricity leakage) remains high at $26 \%$, which was simply lost from the electricity sales while incurring costs of distribution, transmission, and generation and power purchases [4]. In contrast, Bhutan's system loss was less than 5\% [3]. The systems losses in Nepal are caused by technical and commercial factors such as inadequate maintenance, defective meters, power thefts, and billing errors.

In Bhutan, the average retail tariff of $3.7 \mathrm{US}$ cents $/ \mathrm{kWh}$ is nominally lower than the average cost of supply of $4.1 \mathrm{US}$ cents $/ \mathrm{kWh}$. This is because of the subsidies. The effective tariff, including the average subsidy of $1.3 \mathrm{US}$ cents $/ \mathrm{kWh}$, is $5.0 \mathrm{US}$ cents $/ \mathrm{kWh}$. The resultant cost recovery of the sector is adequate at $122 \%$. As for Nepal's tariffs, the electricity prices are relatively high, but still lower than the cost of supply. Therefore, the NEA has been accumulating financial losses over time due to inadequate cost recovery. Of course, the NEA should make more efforts to reduce costs; however, considering the high cost structure of Nepal's systems, some tariff rationalizations cannot be avoided for the purpose of the cost recovery principle, which is the basis of the electricity tariff-setting rules in many countries. It is a fundamental problem that Nepal's tariff adjustment regulatory mechanisms were not functional. The Nepali regulator's capacity has been weak in terms of its power and functions, and it effectively requires the government's consent for tariff revisions. The setting of Nepal's tariff was highly influenced by political considerations, and the cost recovery principle was historically ignored. In effect, Nepal's retail tariffs had been unadjusted for 11 years until 2012 in spite of its high 
inflationary economy. During this period, the costs kept increasing along with inflationary factors, unlike the tariffs. Before the 2012 tariff revisions, the NEA's cost recovery rates continued to deteriorate and stood at merely 78\% in 2011 [29]. Even after the 2012 tariff hike, the costs continued to snowball and the cost recovery rate worsened to $71 \%$ in 2016 as shown in the above table. This suggests that, as the NEA sells more electricity, its deficits continue to increase.

As a result, the NEA has had little budgetary room to invest in new generation, transmission, and distribution projects, and little space to cover even the operating and maintenance costs of the existing facilities. Even worse, the resultant poor maintenance of the systems caused an increase in the system losses from the transmission and distribution systems and reduced the sales and revenue collections against the power supply. Insufficient maintenance also made the power supply unstable and the power supply's quality worsened. More inefficient operations increased costs incurred to the power supply services and resulted in higher overall operational costs far beyond what would be appropriate tariffs if adjusted according to the cost recovery principle. Under the resultant vicious loop (see Figure 3), cost efficiency can become a moot notion while management tends to emphasize volume (quantity) rather than quality (productivity). Thus, the high cost structure of Nepal's hydropower projects, which was observed in some studies [34,37-41], is not irrelevant to the high cost structure of overall management and operations at the corporate and sector levels. Because of power shortages, poor planning, inefficient management and operations, and weak regulatory systems, high-cost corporate culture and systems are deep-rooted and hard to change without any effective institutional reforms, such as functional unbundling to clarify responsibilities and cost structures for the NEA's generation, transmission, and distribution businesses. Thomas (2016) pointed out that the weakness in the overall domestic sector performance has created impediments for cross-border electricity cooperation and power trade capacity [42].

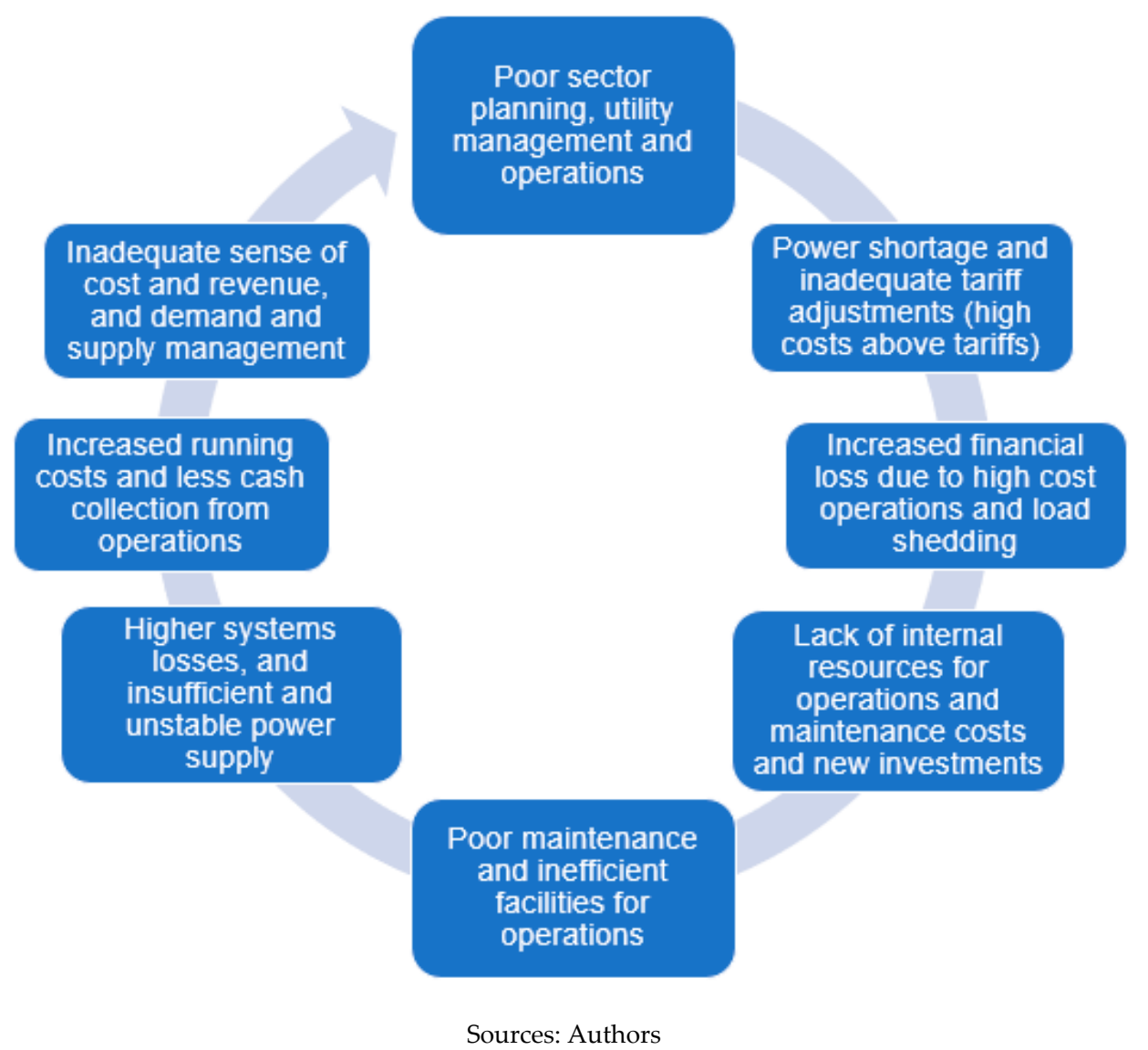

Figure 3. Nepal's vicious circle of inefficient sector planning, management, and operations. 


\subsection{Societal Environmental and Social Sensitivities}

The analytical scope can be shifted from the sector's situation to the societies of both Bhutan and Nepal. This is because hydropower projects are always associated with social and environmental sensitivities and require careful impact assessments in relation to local communities and societies. At the country level, Nepal's environmental degradation has already been salient in some specific aspects. For example, Nepal's deforestation has been extensive. Nepal's forest area as a percentage of its total land area has shrunk from 34\% in 1990 to $25 \%$ in 2015, while Bhutan's forest area has recovered from $54 \%$ to $72 \%$ over the same time period [13]. Forestry management has also had an impact on country-wide hydropower development. In the case of Nepal's Tanahu hydropower project (with a 140 MW storage type), around 160,000 trees were estimated to have been lost from being cut down on the project site or submerged in the reservoir [29]. To compensate for the loss of trees, Nepal's regulations determine the replacement of the affected trees at a ratio of 1:25 [29]. This means that 25 trees need to be newly planted for every tree lost. This requirement significantly increased the project's environmental management costs for tree plantation. In Bhutan, the corresponding ratio is 1:2 for compensatory plantation under the Forest and Nature Conservation Rule, 2017. This indicates that the threat of deforestation has affected different government regulations and hydropower development costs, as well as the entire approach to hydropower planning and development. To maximize generation output and compensate for domestic power shortages, Nepal's project facility structures were often designed to emphasize water volumes in larger reservoir storages and areas of influence, which further increased the project costs and social and environmental impacts on a project level [41]. As a result, Nepal's project implementation became more challenging.

Certainly, hydropower projects contribute to deforestation through the large number of affected trees as seen in the Tanahu project. All the same, as a research group who recently reviewed hydropower projects in Nepal pointed out, without increasing dependency on hydropower, it is hard for Nepal to reduce deforestation, soil erosion, and flooding downstream in the Ganges plain [43]. This is because the main cause of deforestation has been a significant use of fuelwood in the absence of other energy sources in Nepal [37]. The research group reported that Nepal's energy mix is dominated by fuelwood (68\%), agricultural waste $(15 \%)$, animal dung $(8 \%)$, and imported fossil fuel $(8 \%)$, and suggested that access to grid-connected power for nearly half of Nepal's population should be improved by exploiting hydropower resources [43]. Bhutan's fuelwood consumption per capita was also very high [44], but firewood and timber requirements have been strictly regulated by the district-level forestry officers and controlled by the government [45]. Bhutan has also achieved almost total electrification throughout the country. Bhutan's strict forestry management is unlikely to be turned around significantly since the Bhutanese laws have already designated about $50 \%$ of the land as protected areas, and the 2008 constitution stipulates that a minimum of $60 \%$ of the land remain forested [46]. Considering Nepal's much larger land area and population size compared to its limited forestry resources, the impacts of deforestation could be substantially more significant in Nepal in the future. Deforestation would also have other widespread effects in terms of soil erosion, soil fertility, landslide risk, flood control, and loss of biodiversity [37]. Nepal's deteriorated forested areas and resulting afforestation requirements may constitute a domestic internal factor responsible for slowing down hydropower development and rural electrification.

It should be noted that deforestation is the cause of only one of the many conflicts over natural resources, which have been endemic in Nepali society [37]. Conflicts over water resources have also arisen around hydropower, irrigation, fisheries, drinking water, flood control, and tourism (e.g., recreational rafting). For example, Nepal's Kulekhani hydropower plant, which is the only running storage type hydropower station in the country, acquired 233 hectares of agricultural land, forcing 500 households to move. As a result, the irrigation system ran dry and a number of traditional grain-grinding mills went out of business, and many species of fish were lost due to the dry downstream river during the dry season [47]. This power plant was developed only for hydropower generation, but in Nepal there have been domestic requests for and debates over multipurpose dam type projects, 
which can typically cover power generation, irrigation, and flood control to make other potential stakeholders become amenable [48,49]. Although multipurpose projects may bring an array of benefits among the stakeholders, the project facilities can be larger, as well as their corresponding costs and safeguard impacts. The multipurpose dam type may also trigger transboundary water usage within the downstream countries, particularly in India. Nepal's law embraces the integrated water resources management approach to water allocation to avoid conflicts among the categories of users, but this approach has not yet been applied appropriately to a river system [47]. In contrast, Bhutan has hardly known the pressure caused by domestic water conflicts. River water is used mainly for hydropower generation in Bhutan. For irrigation and drinking water, people depend on stream flows from a higher side of the hill; they do not have to fetch the river water in deep valleys near hydropower project sites. In addition, according to the Food and Agriculture Organization's fisheries technical paper [50], unlike in Nepal, there are no full-time fishers or fishing cooperatives dependent on the rivers in Bhutan.

Nepal's conflicts over internal resources have sometimes led to social conflicts. One report for USAID [47] suggested that even the Maoist insurgency had been indirectly rooted in conflicts due to environmental degradation, resource scarcity, social inequality, and concomitant limited access to natural resources and services, coupled with limited economic opportunities outside urban areas, widespread rural poverty, and the Nepali government's weak capacity to control these matters. Similarly, Nepal's social conflicts have manifested themselves historically around hydropower projects. Such projects in Nepal have typically affected a larger number of people than in Bhutan as Nepal's project sites were often selected in large rivers and open valleys with high residential densities to take advantage of the water volume and the resultant increase in domestic power generation [41]. As a direct or indirect consequence of hydropower projects in Nepal, some people were displaced, and livelihoods were also affected due to the degradation or loss of private land and properties, resources, and local infrastructure and amenities [37]. Bhutan's hydropower projects, in contrast, caused only a small number of physical relocations as they were designed to emphasize the efficiency for generation rather than the need for water volume, and resulted in relatively compact facilities with smaller social and environmental impacts [41].

In qualitative terms, Nepal's social conflicts also tend to be complicated. For example, the West Seti hydroelectric project brought into relief the history of various conflicts and difficulties. In March 2009, one of the authors visited the project-affected areas-the reservoir area, the downstream area, and the resettlement area in Terai-and with the site visit team, met with more than 1000 affected persons to hear their opinions and concerns. The project anticipated extensive social impacts. Its resettlement plan estimated the numbers directly affected by the project to be 2421 households (18,269 persons) [51] The first conflict was observed between the affected people in the hilly areas to be submerged and other people in the main host community in the Terai area to which the affected people were initially intended to be relocated. The host community was dominated by the indigenous group of the Tharus, but, because of the large number of incomers, the Tharus feared a sudden change in the composition of residents in the community, and the resulting loss of the Tharus' political majority. In this situation, "the hill people" (i.e., affected people) were also concerned about cultural and economic clashes with the original Tharu residents. Second, there were different views among the hill people. Some farmers were mainly concerned about obtaining good quality land after their displacement, whereas some businessmen were worried about acquiring space in the marketplace [19]. The reactions from the Tharus and other Terai area people were also different. Some businessmen in the host community intended to welcome the newcomers, but others were concerned about having to compete with them. Third, there was division as well as internal conflict among the affected hill people groups. Some people in the reservoir area objected to the project because the people in the higher areas above the reservoir would get less compensation than those in the lower areas to be submerged by the reservoir. The latter group of people basically supported the project because they generally preferred to be relocated to better areas in Terai rather than to hilly areas with no roads, electricity, or good access to public services for education and clinics. Another group of affected people in the 
downstream area would expect to receive some resettlement compensation packages for physical and/or economic losses, and generally seemed to support the project. Fourth, the Dalits in the lowest class of Nepal's caste system were landless and feared losing their patrons and their livelihoods [19]. Other vulnerable people, including female-headed families and the elderly, were anxious about their present ties to their original communities and worried about their future positions and subsistence in different communities after their displacements [19]. Fifth, the government and its local offices ignored any budget allocations to repair bridges, footpaths, and any damaged community facilities because they thought that they would be submerged sooner or later. Some affected people were similarly neglected and their community facilities and forests were not properly maintained.

Nepal's local politics, which revived after the Maoist insurgency, made the situation more complicated. The frustrations of the affected people have remained even though the West Seti hydroelectric project is now being considered by a new developer, China Three Gorges Corporation, after the original Australian firm pulled out. The Arun III project is being promoted by an Indian government-owned utility, Satluj Jal Vidyut Nigam Limited. In Nepal, there are more than 100 hydropower projects under consideration or construction across the country [52]. They include half-dead projects that have been under consideration and preparation for some years. The widespread uncertainties of hydropower project development can create and grow local people's distrust and skepticism about the project developers, the government, and the public utilities, countrywide and at the sector level.

As seen in the above case, Nepali society is quite sensitive to the actions and thoughts of many indigenous peoples, members of the country's religious castes, marginalized people, and local political actors. These various social groups and interests were powerful enough to even delay the process of the new constitution for seven years until it was promulgated in 2015 , bringing about a federal system grouping the seven provinces of the country. For example, the Madeshi, one of the indigenous peoples originating from India, resisted the constitution's provincial divisions and the resultant political power balance shift. They stuck against the revisions and closed the Indian border for more than four months [53]. Local rights have often been stressed by minorities, who comprise 51 listed indigenous peoples and constitute at least $40 \%$ of the population in Nepal [54]. Nepali society has become more complex and political from the center to the periphery, and citizens may make more demands on hydropower development and power exports as part of local rights. Demands may arise immediately when the social impact of a hydropower project is deemed excessive and the project itself is seen as capable of opening a Pandora's box of social issues. In addition, the Nepali society is open and alert to active non-governmental organizations (NGOs). Although the exact number of NGOs working in Nepal is unknown, it was estimated at 60,000 in 2005 by ADB, including 13,000 registered organizations [55].

In contrast, Bhutan has only 30 NGOs [56], and these must be registered with the government [57]. Bhutan also has minority groups, including Nepali-speakers (35\%), and diverse indigenous populations and others (15\%) [58]. The CIA states that the majority of the Bhutanese population comprises three ethnic groups: the Ngalong, the Sarchop, and the Kheng. All of these are culturally integrated to some extent. There are also numerous other ethnic groups with much smaller populations (e.g., the Adivasi, Birmi, Brokpa, Doya, Lepcha, Tibetan, and Toktop). However, no salient political connections with the ethnic groups have been observed in Bhutan, unlike in Nepal. Although Freedom House, an international NGO, highlighted Bhutan's social issues, including employment discrimination against Nepali-speaking citizens and local harassment of non-Buddhists [57], there was not a big difference in the rankings between Bhutan and Nepal in the country assessments for civil liberties (Bhutan was ranked 118th and Nepal was 127th out of 211 countries, and both were assessed as "partly free" [59]).

On the other hand, there is one contrasting societal indicator. Out of 175 countries and territories surveyed in Transparency International's 2014 Corruption Perceptions Index, Bhutan was ranked 30th, whereas Nepal was 131th [60]. The social transparency situation looks better in Bhutan. Sinpeng [61] 
indicates that the wealth created from hydropower exports has increased the income gap among people, but has not, surprisingly, resulted in social unrest or tension. The wealth disparities were mitigated relatively well by the government's redistribution of the power export benefits with guarantees of sufficient land, accommodation, free healthcare, and subsidies for farming activities. As seen in the previous (Section 3.1. Domestic power supply), the export benefit-sharing mechanism, in which export revenues are diverted to socioeconomic purposes, can be considered a crucial tool for alleviating the social disparities in communities and ensuring promotion of hydropower exports.

Given the different factors at play in their respective environmental and social contexts, Bhutan and Nepal both handled their hydropower projects with sensitivity and discretion. Hydropower projects usually have large local impacts in environmental and social terms and therefore hydropower projects are inclined to be sensitive to local requirements. In the case of Nepal, local demands tend to be stronger based on diverse complexities and competition in local areas; as a result, hydropower development can be vulnerable to grass-root anxieties as well as desires. This background can explain, in the case of Nepal's projects, the increased costs of environmental and social safeguards, including extensive community support. On the other hand, Bhutan's local environmental and social situation is relatively uncomplicated, but the government's benefit-sharing mechanism from power exports has contributed to mitigating social inequalities and disparities among the social classes. This suggests that Bhutan's hydropower projects can be rather resilient to local demands. The hydropower projects' safeguards, impacts, and development pace can be adapted, to some degree, to each country's environmental and social characteristics and their safety net mechanisms.

\section{Conclusions}

This analysis of the barriers to hydropower development and concomitant trade opportunities took into account the internal factors at play both at the country and sector levels. These factors are varied and include such elements as the pressure to prioritize domestic electricity supply over power exports, sector reform's influence on institutional capacity and cost recovery, and societal, environmental, and social resilience. These constraints are deep-rooted, and the analysis of domestic factors underscored the importance of internal stakeholders and circumstances and the need to reserve them a space in defining policy related to hydropower development and concomitant trade promotion. There were some clarifications of the causal effects. For example, the push to export electricity tends to receive severe reactions from the public within the context of domestic power scarcity and the load-shedding blackouts experienced by both urban and rural residential customers. Under continued blackouts in daily life, power export project proposals would be not only a local concern regarding the project location, but also a nation-wide concern. However, this situation could gradually be overcome by means of judicious policy interventions as demonstrated in Bhutan. These include (i) avoidance of load shedding to residential customers, (ii) giving priority to electricity for domestic consumption rather than power export, (iii) mechanisms for sharing the benefits of power export, and (iv) progressive implementation of a rural electrification master plan. It is wise to make the relationship between domestic power supply and power export visible without having them in conflict. Power exports can be promoted in parallel with rural electrification programs in a virtuous circle as seen in Bhutan where public acceptance of electricity export was valued as the first priority.

In Nepal, the first step should be to minimize and eliminate load shedding and meet the current domestic power demand, setting aside the issue of potential future demand from currently unelectrified customers. To do this, ongoing power imports from India should be continued and increased as an immediate measure. This makes it necessary to increase the capacity of transmission interconnections as soon as possible. These transmission systems, even if built for power imports from India, can be used for power exports to India if/when Nepal identifies any surplus in the future. Therefore, the necessity of immediate investments to augment the interconnected transmission capacity is evident and inarguable. Second, in the planning of power generation, the domestic power supply should be prioritized over power export arrangements. As much as possible, power should be exported 
only from the surplus remaining after the domestic demand is met. In the case of private sector power export projects, however, a certain portion of power generated should always be taken by the government as an energy royalty and designated for domestic electricity consumption in a clear policy provision. Third, Nepal should formulate a detailed master plan to implement rural electrification to enhance residential access to electricity and resolve concerns about the potential scarcity that might result from exporting electricity. Fourth, the benefit-sharing mechanism related to the royalty system should be built into the domestic electricity pricing systems while promoting rural electrification programs in parallel. This would allow Nepal to improve public support for hydropower projects despite the fear of export-caused electricity scarcity and before achieving full electrification. As in Bhutan, these four policy interventions can be applied in Nepal to gradually end the vicious circle of hydropower project development.

The second point of focus in the analysis of domestic factors as barriers was the significance of domestic stability and sector reforms for devising consistent policies and adequate governance systems. Unlike Bhutan, Nepal has been in political turmoil for decades. Sectoral reforms were delayed and the sector performance deteriorated during this period; as a result, the sectoral and institutional cost recovery is unsustainable. Because of frequent changes of government and inadequate leadership, sectoral autonomy, corporate planning, and management efficiency were weakened. Over time, these issues cascaded down to the project site management level. The sense of cost and operational efficiency was diminished, and quantity (volume) was prioritized over quality (productivity) in planning and management. Thus, Nepal's high cost structure has been maintained at the sector, institutional, and project levels. This, clearly, is a deep-rooted vicious circle and cannot be turned around without implementing appropriate economic and sector reforms. Such reforms were carried out in Bhutan to improve the sector's efficiency. The ADB, World Bank, and other bilateral aid agencies recommended a series of sector reform plans to Nepal, but the government has not adopted any major activities, including the NEA restructuring plan, because of the lack of consensus within the Nepali coalition governments. Due to the lack of progress in reforms, the ADB postponed new energy projects for several years in the 2000s, but the sector performance has further worsened since then. This indicates that Nepal's power sector reforms cannot be done from the outside but should be agreed on first within the country.

The third point in this analysis involved an assessment of domestic environmental and social sensitivities. Because of widespread deforestation in $75 \%$ of its total land area, Nepal's hydropower development has been under pressure from an aggressive afforestation requirement. In addition, to mitigate domestic water related conflicts in Nepal, there have been calls for multipurpose dam type projects for power generation, irrigation, and flood control. These two domestic pressure sources are likely to increase hydropower project costs and make projects more challenging. In contrast, Bhutan has reconstituted its forest coverage to $72 \%$, and has had much less concern about potential internal water conflicts so far; hence, there are no multipurpose dam schemes for domestic purposes in Bhutan. The contrasting situations that the two countries find themselves in are attributable to their different usages of the river water, their population sizes, and their levels of electrification. Regarding the social context, many indigenous peoples, religious castes, and local political actors that are part of Nepal's complex social fabric have played an active role in the social conflicts that arose around large hydropower projects with significant resettlements. Bhutan has had fewer issues in this regard as the impacts of resettlement were reduced by the project designs. As for the overall results, Bhutan's hydropower development tends to be resilient to domestic environmental and social pressures, whereas Nepal's development has been vulnerable to complex domestic requirements. Due to safeguard concerns, the pace of Nepal's project development should have decreased. It is crucial for Nepal to plan and prepare hydropower projects and their purposes with careful attention to risks arising from resource conflicts and social complexities.

While this paper focuses on domestic influences on the differences in the hydropower development and export tracks between Bhutan and Nepal, external influences are still significant 
for the results. In particular, a separate analysis was conducted of the foreign diplomacy of the two countries in their relationships with India, China, and Bangladesh, which have historically influenced both countries' hydropower development and exporting. This analysis will be presented in a subsequent paper. Further research could also be conducted to check if these analytical outcomes can be applied to other hydropower-rich developing countries, such as Myanmar and Laos.

Author Contributions: K.O. prepared the original draft; M.N. supervised research and acquired funding; D.S. reviewed and edited the whole manuscript for submission. All authors read and approved the final manuscript.

Funding: This work was supported by JSPS KAKENHI Grant Number JP17K18578, the 21st Century Culture and Academic Foundation, and the University of Tokyo Graduate School of Frontier Sciences.

Conflicts of Interest: The authors declare no conflict of interest.

\section{References}

1. Nakayama, M.; Maekawa, M. Economic benefits and security implications of trading hydropower through transboundary power grids in Asia. Int. J. Water Resour. Dev. 2013, 29, 501-513. [CrossRef]

2. World Bank. NEPAL Country Snapshot; World Bank: Washington, DC, USA, 2015; Available online: http://documents.worldbank.org/curated/en/816301468190763519/pdf/100117-WP-PUBLICBox393225B-Nepal-country-snapshots.pdf (accessed on 16 August 2017).

3. Bhutan Power Corporation (BPC). Power Data Book 2015; Bhutan Power Corporation: Thimphu, Bhutan, 2016.

4. Nepal Electricity Authority (NEA). A Year-in Review: Fiscal Year 2015/16; NEA: Kathmandu, Nepal, 2016.

5. Government of Nepal. National Population and Housing Census 2011 (National Report); National Planning Commission Secretariat, Central Bureau of Statistics, Government of Nepal: Kathmandu, Nepal, 2012.

6. Dukpa, S. Personal communication, 2016. Interviews by the author (Ogino) with Mr. Dukpa, government of Bhutan. 2016 August 1.

7. World Bank. World Development Indicators: GDP per Capita; World Bank: Washington, DC, USA, 2017; Available online: http://data.worldbank.org/indicator/NY.GDP.PCAP.CD?locations=NP (accessed on 22 April 2017).

8. Asian Development Bank (ADB); National Statistics Bureau, Bhutan. Bhutan Living Standards Survey 2012 Report; ADB: Manila, Philippines; National Statistics Bureau: Thimphu, Bhutan, 2013. Available online: https:/ / www.adb.org/sites/default/files/publication/30221/bhutan-living-standards-survey-2012. pdf (accessed on 16 August 2017).

9. Asian Development Bank (ADB). Proposed Loans, Asian Development Fund Grant, Technical Assistance Grant, and Administration of Grant, Bhutan: Green Power Development Project; ADB: Manila, Philippines, 2008.

10. Bhutan Electricity Authority (BEA). Bhutan Power Corporation Limited Tariff Review Report; BEA: Thimphu, Bhutan, 2013.

11. Bhutan Electricity Authority (BEA). Bhutan Power Corporation 2016-2019 Tariff Review Report; BEA: Thimphu, Bhutan, 2017. Available online: http://www.bea.gov.bt/wp-content/uploads/2017/03/BPC_Tariff_ Review_Report_2016-19.pdf (accessed on 16 August 2017).

12. Nepal Electricity Authority (NEA). A Year-in Review: Fiscal Year 2014/15; NEA: Kathmandu, Nepal, 2015.

13. World Bank. World Development Indicators: Population, Total; Land Areas (sq.km); Forest Area (\% of Land Area); World Bank: Washington, DC, USA, 2017; Available online: http://databank.worldbank.org/data/reports. aspx? source $=2 \&$ series $=$ SP.POP.TOTL\&country $=$ BTN (accessed on 18 November 2017).

14. World Bank. Project Paper on A Proposed Additional Credit in the Total amount of SDR 24.6 Million (US37.0 Million Equivalent) and A Proposed Additional Grant in the Total Amount of SDR 1.4 Million (US\$2.0 Million equivalent_to Nepal for the Nepal-India Electricity Transmission and Trade Project; World Bank: Washington DC, USA, 2013.

15. Fowler, P. Energy and Security in South Asia: Cooperation or Conflict? Asian Aff. 2012, 43, 312-313. [CrossRef]

16. Ebinger, C. Energy and Security in South Asia; Cooperation or Conflict? Brookings Institution: Washington, DC, USA, 2011.

17. Berkoff, J. Hydropower in Bhutan and Nepal. Why the difference? World Econ. 2003, 4, 121-142. 
18. Biswas, A.K. Cooperation or conflict in transboundary water management: Case study of South Asia. Hydrol. Sci. J. 2011, 56, 662-670. [CrossRef]

19. Koirala, S.; Hill, D.; Morgan, R. Impacts of the delay in construction of a large-scale hydropower project on potential displaces. Impact Assess. Proj. Apprais. 2017, 35, 106-116. [CrossRef]

20. Strahorn, E. An Analysis of the Barriers to Cross Border Trade in Hydroelectricity in the Himalayas; The Himalayan Research Papers Archive: Albuquerque, NM, USA, 2016.

21. Armbrecht, A. Defining the "Local" in the Arun Controversy: Villagers, NGOs, and the World Bank in the Arun Valley, Nepal; Cultural Survival Quarterly Magazine: Cambridge, MA, USA, 1996; Available online: https: / / www.culturalsurvival.org/publications / cultural-survival-quarterly / defining-local-aruncontroversy-villagers-ngos-and-world (accessed on 2 October 2017).

22. Pallas, C. Transnational Civil Society and the World Bank: Investigating Civil Society's Potential to Democratize Global Governance; Springer: Berlin, Germany, 2013.

23. Rest, M. Generating power: debates on development around the Nepalese arun-3 hydropower project. Contemp. South Asia 2012, 201, 105-117. [CrossRef]

24. Coats, C. Tunisian Renewable Project Spur Interest in Europe. 2016. Available online: https: / www.forbes.com/sites/christophercoats/2016/06/30/tunisian-renewable-project-spur-interestin-europe/\#79e686f0995e (accessed on 15 August 2017).

25. Asian Development Bank (ADB). Completion Report, Bhutan: Green Power Development Project; ADB: Manila, Philippines, 2017.

26. Japan International Cooperation Agency (JICA). The Integrated Master Plan Study for Dzongkhag-Wise Electrification in Bhutan; JICA: Tokyo, Japan, 2005.

27. Price, G.; Mittra, S. Water, Ecosystems and Energy in South Asia-Making Cross-Border Collaboration Work; The Royal Institute of International Affairs Chatham House: London, UK, 2016.

28. Adhikari, M.; Pahari, B.R.; Shrestha, R. Analysis of Rural Electrification Policy Provisions in Nepal. In Proceedings of the IOE Graduate Conference, Kathmandu, Nepal, 10-11 October 2014; pp. 260-268. Available online: http:/ / conference.ioe.edu.np/ioegc2014/papers/IOE-CONF-2014-34.pdf (accessed on 16 August 2017).

29. Asian Development Bank (ADB). Proposed Loans and Administration of Technical Assistance Grant, Nepal: Tanahu Hydropower Project; ADB: Manila, Philippines, 2013.

30. Ogino, K.; Hamanaka, S. Case Story on Cross-Border Power Export from Dagachhu Hydropower Development_Green Power Development Project_Asian Development Bank; OECD: Paris, France, 2011; Available online: https: / /www.oecd.org/aidfortrade/48651659.pdf (accessed on 15 August 2017).

31. International Monetary Fund (IMF). Nepal: 2017 Article IV Consultation-Press Release; Staff Report, IMF Country Report No.12/326; IMF: Washington, DC, USA, 2017.

32. Gippner, O. Energy Cooperation in South Asia: Prospects and Challenges (VIII+54); South Asia Watch on Trade, Economics and Environment (SAWTEE): Kathmandu, Nepal, 2010.

33. Janssen, P. Nepal's Political Uncertainty Discourages Foreign Investment. 2016. Available online: https:/ / asia.nikkei.com/Politics-Economy/Economy/Nepal-s-political-uncertainty-discouragesforeign-investment (accessed on 15 August 2017).

34. British Power International (BPI). Nepal-Removing Barriers to Hydropower Development; BPI: Kathmandu, Nepal, 2009.

35. Singh, A.; Jamasb, T.; Nepal, R.; Toman, M. Cross-Border Electricity Cooperation in South Asia; Policy Research Working Paper 7328; World Bank: Washington, DC, USA, 2015.

36. Asian Development Bank (ADB). Performance Evaluation Report-Nepal: Kali Gandaki "A" Hydroelectric Project; ADB: Manila, Philippines, 2012.

37. Asian Development Bank (ADB); International Centre for Integrated Mountain Development (ICMOD). Environment Assessment of Nepal: Emerging Issues and Challenges; ADB: Kathmandu, Nepal; ICMOD: Kathmandu, Nepal, 2006.

38. Dixit, A.; Gyawali, D. Nepal's Constructive Dialogue on Dams and Development. Water Altern. 2010, 3, 106-123.

39. Gyawali, D.; Thompson, M.; Verweij, M. Aid, Technology and Development: The Lessons from Nepal; Routledge: New York, NY, USA, 2017.

40. Jalsot Vikas Sanstha (JVS). Hydropower Pricing in Nepal-Developing a Perspective; JVS: Kathmandu, Nepal, 2004. 
41. Ogino, K. Fundamental Barriers to Cross-Border Power Trading of Bangladesh, Bhutan, India, and Nepal (BBIN)_Comparative Study on Development of Hydropower Resources in Bhutan and Nepal; The University of Tokyo: Tokyo, Japan, 2018.

42. Toman, M.; Jamasb, T.; Karacsonyi, J.; Nepal, R.; Singh, A.; Diego, L.; Timilsina, G. Regional Electricity Cooperation and Trade in South Asia: Economic Benefits and Regulatory Challenges. In Proceedings of the European Association of Environmental and Resource Economists 22nd Annual Conference, Zurich, Switzerland, 22-25 June 2016; Available online: http:/ / www.webmeets.com/files / papers/EAERE/2016/ 1234/South\%20Asia\%20Regional\%20Electricity\%20Trade_benefits\%20and\%20challenges.pdf (accessed on 20 July 2017).

43. Alam, F.; Alam, Q.; Reza, S.; Khurshid-ul-Alam, S.M.; Saleque, K.; Chowdhury, H. A review of hydropower projects in Nepal. Energy Procedia 2016, 110, 581-585. [CrossRef]

44. Asian Development Bank (ADB). Proposed Grant Kingdom of Bhutan: Rural Renewable Energy Development Project; ADB: Manila, Philippines, 2010.

45. Webb, E.L.; Dorji, L. The evolution of forest-related institutions in Bhutan: Adaptation of Local People to the Rising State. In Decentralization, Forests and Rural Communities: Policy Outcomes in South and Southeast Asia; Webb, E.L., Shivakoti, G.P., Eds.; Saga Press: Noida, India, 2004; pp. 68-92.

46. Premkumar, L. A Study of the India-Bhutan Energy Cooperation Agreements and a Study of the India-Bhutan Energy Cooperation Agreements and the Implementation of Hydropower Projects in Bhutan; Vasudha Foundation: New Delhi, India, 2016.

47. Associates in Rural Development (ARD). Conflict over Natural Resources at the Community Level in Nepal Including Its Relation to Armed Conflict; ARD: Burlington, VT, USA, 2006.

48. Aryal, M. Revisiting a multi-purpose Melamchi-The only way to save the project may be to expand it to include hydropower and irrigation. Nepali Times. 21 December 2007. Available online: http://nepalitimes. com/news.php?id=14295\#.WgZvOGdlL4g (accessed on 6 November 2017).

49. Investment Board Nepal. Energy Sector Profile; Investment Board Nepal: Kathmandu, Nepal, 2017.

50. Petr, T. Fish and Fisheries at Higher Altitudes: Asia; FAO Fisheries Technical Paper, No. 385; FAO: Rome, Italy, 1999.

51. Asian Development Bank (ADB). Resettlement Planning Document, NEP: West Seti Hydroelectric Project, Reservoir Area and Downstream Project; ADB: Manila, Philippines, 2008.

52. Bhushal, R. Will China Invest in Nepal's Hydropower Plants? The Third Pole. 2007. Available online: https: / www.thethirdpole.net/2016/03/17/will-china-invest-in-nepals-hydropower-plants / (accessed on 6 November 2017).

53. Shastri, S. Nepal: Why Are the Madhesis Not Willing to Compromise? National Institute of Advanced Studies: Bangalore, India, 2016.

54. Nilsson, C.; Stidsen, S. Constitutional Politics and Indigenous Peoples in Nepal; International Work Group for Indigenous Affairs (IWGIA): København, Denmark, 2014.

55. Asian Development Bank (ADB). Civil Society Brief-Overview Civil Society: Nepal; ADB: Manila, Philippines, 2005.

56. Asian Development Bank (ADB). Civil Society Brief: Bhutan; ADB: Manila, Philippines, 2013.

57. Freedom House. Freedom in the World 2016: Bhutan Country Report; Freedom House: Washington, DC, USA, 2016.

58. Central Intelligence Agency (CIA). The World Fact Book, Bhutan; CIA: Washington, DC, USA, 2017.

59. Freedom House. Freedom in the World 2017; Freedom House: Washington, DC, USA, 2017.

60. Transparency International. Transparency International Corruption Perceptions Index 2016; Transparency International: Berlin, Germany, 2017; Available online: http:/ /www.ey.com/Publication/vwLUAssets/EYTransparency-International-Corruption-Perceptions-Index-2016/\$FILE/EY-Transparency-InternationalCorruption-Perceptions-Index-2016.pdf (accessed on 6 November 2017).

61. Sinpeng, A. Democracy from Above: Regime Transition in the Kingdom of Bhutan. J. Bhutan Stud. 2007, 17, 21-48. 